\title{
Peningkatan Keterampilan PKK Perak Asri Kabupaten Bantul Melalui Produk Ecoprint Ramah Lingkungan dan Berdaya Saing
}

\author{
Genesiska, Diah Rina Kamardiani, Sukuriyati Susilo Dewi, Nur Rokhim, Eka Fitriastuti \\ Program Studi Agroteknologi, Fakultas Pertanian, Universitas Muhammadiyah Yogyakarta \\ Jalan Brawijaya, Kasihan, Bantul Yogyakarta 55183 \\ Email:genesiska@umy.ac.id \\ DOI: 10.18196/ppm.31.135
}

\begin{abstract}
Abstrak
Kegiatan produksi ecoprint sedang marak dilakukan oleh pelaku usaha maupun komunitas, termasuk Kelompok Pemberdayaan Kesejahteraan Keluarga (PKK) Perak Asri di Kabupaten Bantul. Kegiatan pewarnaan melalui media ini memiliki peluang dan potensi besar yang perlu dikembangkan terkait dengan ketertarikan masyarakat terhadap produk variatif ramah lingkungan dan peningkatan nilai ekonomi produk yang dapat memberikan nilai kesejahteraan bagi masyarakat. Akan tetapi, terdapat beberapa kendala produksi ecoprint untuk dapat dikomersialkan dengan kualitas baik berdaya saing dan ramah terhadap lingkungannya. Dalam program kemitraan masyarakat ini, dilakukan beberapa upaya untuk meningkatkan kapasitas Kelompok PKK Perak Asri melalui beberapa agenda kegiatan yaitu pertama penyuluhan dalam pemahaman mengenai konsep ecoprint ramah lingkungan, kedua pendampingan dalam pendaftaran merek dagang produk, ketiga penyuluhan dan pendampingan metode dye blanket, dan keempat serah terima fasilitas pendukung produksi ecoprint dalam skala lebih besar. Program kemitraan masyarakat dengan tujuan peningkatan keterampilan PKK Perak Asri Kabupaten Bantul melalui produk ecoprint ramah lingkungan dan berdaya saing secara keseluruhan memberikan tingkat kepuasan kategori puas sebesar 56 persen, kategori cukup puas sebesar 44 persen dilihat dari kesesuaian rencana dan solusi yang digunakan, sedangkan 44 persen sebagai persentase kategori puas dan 56 persen kategori cukup puas terhadap pemanfaatan secara maksimal bagi PKK Perak Asri Kabupaten Bantul, Daerah Istimewa Yogyakarta.
\end{abstract}

Kata Kunci: berkelanjutan; ecoprint; ikon; keterampilan; PKK Perak asri

\section{Pendahuluan}

Kelompok Pemberdayaan Kesejahteraan Keluarga (PKK) Perak Asri merupakan sekelompok wanita aktif dalam organisasi masyarakat di Kabupaten Bantul, D.I. Yogyakarta yang berjumlah 20 orang. Kegiatan rutin yang diselenggarakan masih sangat minimalis tanpa program pemberdayaan yang menghasilkan nilai ekonomi produk yang signifikan dapat memberikan nilai kesejahteraan anggotanya. Biasanya, kegiatan yang dilakukan hanya tamanisasi, posyandu, program lansia maupun partisipasi festival kemasyarakatan. Padahal, terdapat potensi wirausaha yang dikembangkan oleh anggota kelompoknya

Potensi yang dimaksud yaitu kemampuan dalam memproduksi produk kain bermotif khas dengan teknik pewarnaan khusus dan alami yang disebut Ecoprint. Teknik pewarnaan ini merupakan teknik pembuatan motif kain yang sedang tren di kalangan masyarakat. Dalam prosesnya, dedaunan maupun bunga segar yang dikoleksi dari lingkungan sekitarnya dapat digunakan sebagai pola motif kemudian pewarna yang digunakan pun diolah dari ekstrak daun yang berpotensi memberikan aksen warna. Teknik ecoprint sudah dikenal oleh kalangan masyarakat di Indonesia maupun negara lain dan menarik perhatian animo masyarakat saat ini. Kegiatan pewarnaan ini memiliki peluang besar yang perlu dikembangkan terkait dengan ketertarikan masyarakat terhadap produk ramah lingkungan dan peningkatan nilai ekonomi produk yang dapat memberikan nilai kesejahteraan bagi masyarakat. Akan tetapi, terdapat beberapa kendala produksi ecoprint untuk dapat dikomersialkan dengan kualitas berdaya saing dan ramah lingkungan.

Selama ini, dari segi produksi pembuatan ecoprint memiliki banyak keterbatasan yaitu: 
keterbatasan dalam menjaga kesegaran material dari dedaunan dan bunga untuk pola motif, keterbatasan dalam teknik mencetak pola motif dari material alami sehingga belum maksimal dalam menunjukkan keindahan anatomi tumbuhan maupun penataannya, keterbatasan dalam packaging produk yang memiliki ciri khas dan layak jual, dan keterbatasan dalam mengembangkan varian produk kain menjadi berbagai bentuk produk jual. Berbagai keterbatasan dari segi produksi khususnya desain dan teknik tersebut dapat mempengaruhi kualitas produk ecoprint. Sehingga nilai produk belum layak jual untuk dinikmati berbagai kalangan.Selain itu, terdapat permasalahan dewasa ini muncul terkait dengan dampak produksi ecoprint terhadap lingkungannya. Walaupun diyakini bahwa produktivitas ecoprint ini memiliki sifat lebih ramah terhadap lingkungan dibandingkan dengan produksi batik, akan tetapi beberapa larutan dan teknik yang digunakan belum diyakini seluruhnya bersifat ramah terhadap lingkungannya.

Oleh karena itu, perlu dilakukan suatu upaya peningkatan keterampilan anggota Pemberdayaan Kesejahteraan Keluarga (PKK) Perak Asri di Kabupaten Bantul melalui produk ecoprint ramah lingkungan dan berdaya saing

\section{Metode Pelaksanaan}

Untuk mencapai target luaran sesuai permasalahan prioritas yang dihadapi, dilakukan berbagai upaya pelaksanaan dengan beberapa metode yang meliputi penyuluhan, fasilitasi peralatan, transfer teknologi, pelatihan dan praktik aplikasi teknologi, pendampingan, dan monitoring evaluasi. Rincian metode pelaksanaan kegiatan selengkapnya disajikan pada Tabel 1 berikut.

\begin{tabular}{|c|c|c|}
\hline \multicolumn{3}{|r|}{ lingkungan dan berdaya saing } \\
\hline No. & $\begin{array}{l}\text { Target Luaran } \\
\text { Kegiatan }\end{array}$ & Metode Pelaksanaan \\
\hline 1 & $\begin{array}{l}\text { Jasa penyuluhan dalam } \\
\text { pemahaman mengenai konsep } \\
\text { ecoprint ramah lingkungan }\end{array}$ & $\begin{array}{l}\text { Penyuluhan } \\
\text { Kegiatan dilakukan dengan cara penyuluhan kepada anggota kelompok PKK dari CEO } \\
\text { Lemospires, Puthut Ardianto, M.Pd. melalui presentasi dan pemutaran video contoh } \\
\text { produksi ecoprint ramah lingkungan untuk mengatasi keterbatasan pemahaman tim mitra } \\
\text { dalam produksi ecoprint berkelanjutan dan lebih ramah lingkungan }\end{array}$ \\
\hline 2 & $\begin{array}{l}\text { Jasa pendampingan dalam } \\
\text { pendaftaran merek dagang } \\
\text { produk }\end{array}$ & $\begin{array}{l}\text { Memberikan pendampingan dalam bentuk workshop kepada anggota PKK Perak Asri } \\
\text { dalam meningkatkan kualitas produk ecoprint siap didaftarkan merek dagangnya secara } \\
\text { online atau ke kantor wilayah kementrian Hukum dan HAM, D.I. Yogyakarta sebagai } \\
\text { motivasi untuk mengatasi keterbatasan dalam packaging produk yang memiliki ciri khas, } \\
\text { layak jual, dan }\end{array}$ \\
\hline 3 & $\begin{array}{l}\text { Jasa penyuluhan dan } \\
\text { pendampingan metode dye } \\
\text { blanket }\end{array}$ & $\begin{array}{l}\text { Pelatihan dan monitoring kegiatan dye blanket sebagai kegiatan praktik meningkatkan } \\
\text { kedalaman materi dan keterampilan ibu ibu PKK Perak Asri dalam produksi ecoprint } \\
\text { untuk menanggulangi keterbatasan dalam teknik mencetak pola motif dari material alami } \\
\text { dan menunjukkan keindahan anatomi tumbuhan maupun penataannya }\end{array}$ \\
\hline 4 & $\begin{array}{l}\text { Serah terima fasilitas pendukung } \\
\text { produksi ecoprint untuk skala } \\
\text { lebih besar }\end{array}$ & $\begin{array}{l}\text { Tim PKK Perak Asri difasilitasi memiliki showcase (kulkas) dan box penyimpan untuk } \\
\text { mengatasi keterbatasan dalam menjaga kesegaran material dari dedaunan dan bunga } \\
\text { untuk pola motif. }\end{array}$ \\
\hline
\end{tabular}

\section{Hasil dan Pembahasan \\ Konsolidasi dengan mitra "PKK Perak Asri" Kabupaten Bantul terkait Rencana Program}

Kegiatan konsolidasi dengan tim PKK Perak Asri mitra yaitu Ibu Erna Herawati sebagai ketua dan 4 pengurus lainnya telah dilakukan pada tanggal 29 Juli 2020. Saat konsolidasi dengan mitra, digali informasi mengenai kesibukan dan pengembangan hasil karya tim saat pandemi dalam berkegiatan produksi ecoprint. Dari kunjungan ini, disampaikan bahwa terdapat banyak kreasi baru dari kain dan kulit dengan motif ecoprint yang dihasilkan dalam beberapa 
minggu terakhir ini yaitu penggunaan kulit domba dan sapi untuk pembuatan tas, sepatu, dan sandal (Gambar 1). Terdapat kebaharuan variasi produk tidak hanya kain dan baju siap pakai. Akan tetapi, mitra menyampaikan kendala dalam segi produksi masih ada. Kendala yang dimaksud dalam produksi yaitu material atau daun tanaman yang mudah layu, dan ekstrak pewarna alami yang belum diproduksi sendiri (konsumtif) sebagai kendala produksi (Gambar 1).
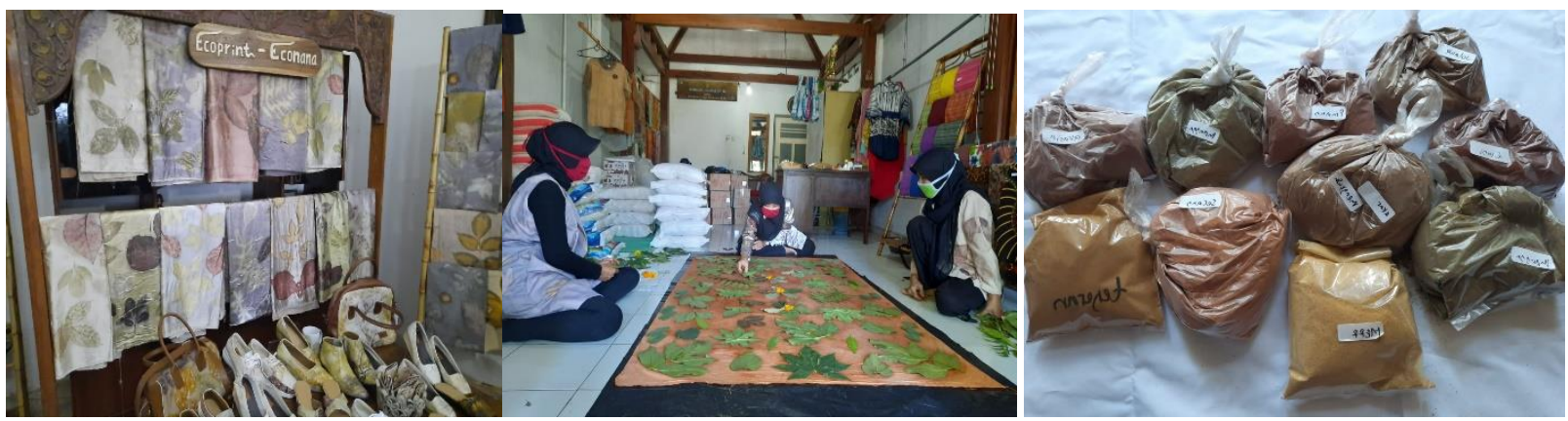

Gambar 1. Informasi hasil pengembangan dan keterbatasan produksi Ecoprint oleh tim PKK Perak Asri sebelum program dilaksanakan. Keterangan: Variasi Produk ecoprint semakin beragam (kiri), material atau daun tanaman yang mudah layu sebagai kendala persiapan produksi (tengah), dan ekstrak pewarna alami yang belum diproduksi sendiri sebagai kendala meminimalisir biaya produksi (kanan).

Dari keterbatasan yang bersifat urgent dalam proses produksi tersebut, kemudian dilakukan diskusi baik dari tim mitra maupun tim pengabdian (Gambar 2) untuk perencanaan program yang diasumsikan dapat menanggulangi permasalahan dalam produksi ecoprint.

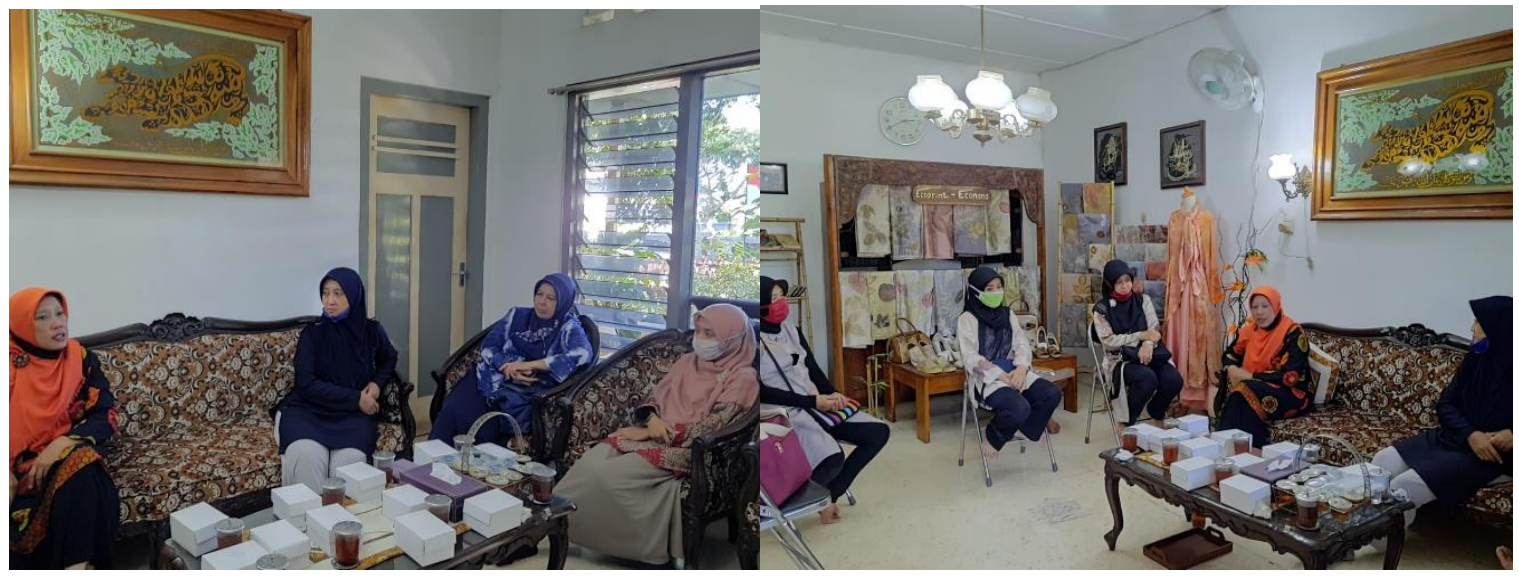

Gambar 2. Konsolidasi dengan pengurus PKK Perak Asri Kabupaten Bantul, D.I. Yogyakarta sebagai produsen ecoprint pada tanggal 29 Juli 2020

Dari hasil konsolidasi kemudian diputuskan bahwa terdapat 4 rencana kegiatan inti dari program kemitraan ini yaitu pertama penyuluhan dalam pemahaman mengenai konsep ecoprint ramah lingkungan, kedua pendampingan dalam pendaftaran merek dagang produk, ketiga penyuluhan dan pendampingan metode dye blanket, dan keempat serah terima fasilitas pendukung produksi ecoprint dalam skala lebih besar. 


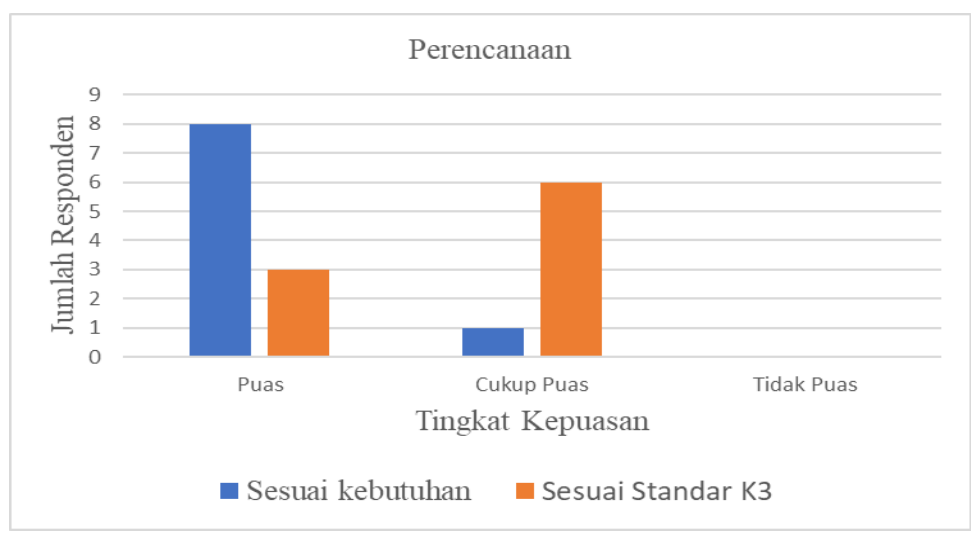

Gambar 3. Tingkat kepuasan anggota mitra PKK Perak Asri terhadap perencanaan program kemitraan kepada masyarakat

Dari beberapa rencana kegiatan inti tersebut, diyakini mitra mendapatkan tingkat kepuasan mitra cukup tinggi terkait dengan kesesuaian kebutuhan mitra dan kesesuaian standar K3 yang diberlakukan dalam program ini, data dapat dilihat pada Gambar 3.

\section{Sosialisasi Konsep Produksi Ecoprint Ramah Lingkungan}

Saat ini, diyakini terdapat suatu proses pencetakan atau printing motif pada suatu media seperti kain yang lebih ramah lingkungan dibandingkan batik yaitu produksi ecoprint. Akan tetapi, kegiatan mordanting atau biodyes ini sebenarnya masih memiliki dampak terhadap lingkungannya. Sehingga penting dilakukan modifikasi dari penggunaan mordant dan pewarna alami (Mutiara Triwiswara, 2015).

Oleh karena itu, pemahaman konsep produksi ecoprint yang lebih ramah terhadap lingkungannya dilakukan pada tanggal 19 September 2020 dengan mengundang salah satu pakar ecoprint yaitu Bapak Puthut Ardianto, M.P. selaku CEO Lemospires yang konsen terhadap ecoprint berkelanjutan. Dalam kegiatan ini dilakukan peningkatan kesadaran masyarakat dalam Teknik pengambilan sampel tanaman sebagai pola motif, dan modifikasi penggunaan mordant dan biodyes yang terangkum dalam konsep $4 \mathrm{P}$ (Product, People, Planet, and Profit). Berikut merupakan dokumentasi kegiatan tersebut pada Gambar 4.

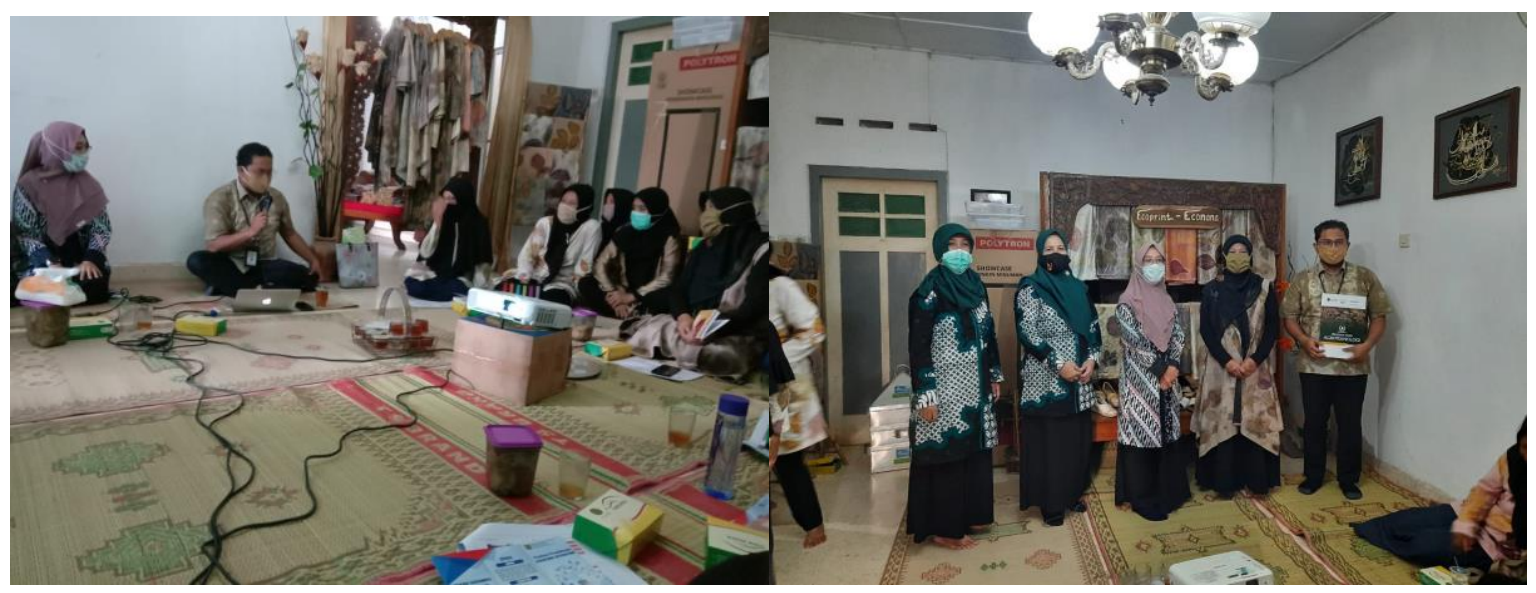

Gambar 4. Sosialisasi Konsep Produksi Ecoprint Ramah Lingkungan kepada PKK Perak Asri pada tanggal 19 September 2020

Kemudian terkait dengan kepuasan mitra terkait dengan sosialisasi konsep ecoprint berkelanjutan memiliki 8 dari 9 orang yang diundang menyebutkan puas terkait dengan kegiatan yang terlaksana, Gambar 5. 


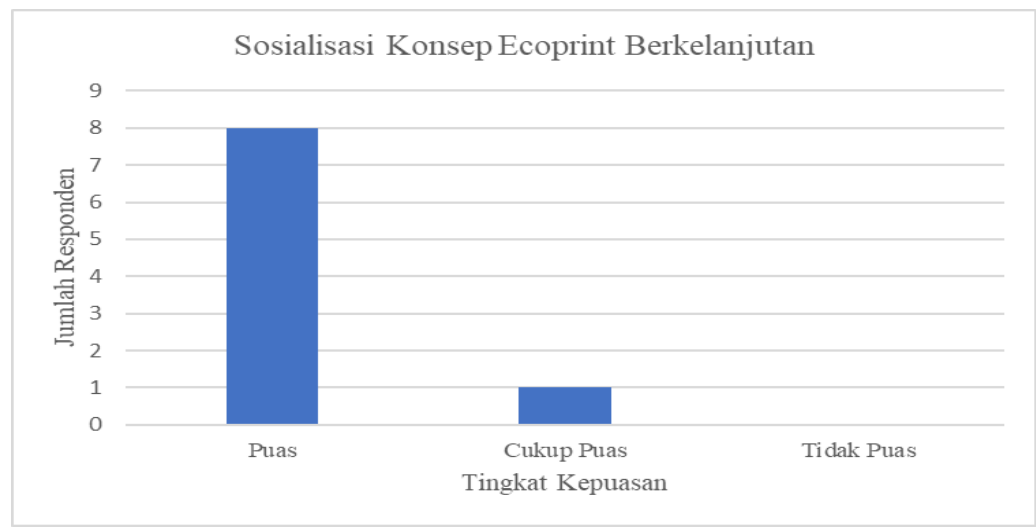

Gambar 5. Tingkat kepuasan anggota mitra PKK Perak Asri terhadap kegiatan sosialisasi ecoprint berkelanjutan

\section{Sosialisasi Perlindungan Hak Kekayaan Intelektual dan Pendaftaran Merek Dagang}

Masyarakat pada umumnya belum mengenal lebih dalam mengenai perlindungan dari hak kekayaan intelektual seperti halnya merek dagang. Menurut Direktorat Jenderal Kekayaan Intelektual (2020), merek adalah tanda yang dapat ditampilkan secara grafis berupa gambar, logo, nama, kata, huruf, angka, susunan warna, dalam bentuk 2 (dua) dimensi dan/atau 3 \{tiga) dimensi, suara, hologram, atau kombinasi dari 2 (dua) atau lebih unsur tersebut untuk membedakan barang dan/atau jasa yang diproduksi oleh orang atau badan hukum dalam kegiatan perdagangan barang dan/atau jasa.

Dari pengenalan merek dagang dan pelatihan (workshop) prosedur pendaftaran merek bertujuan meningkatkan minat dan motivasi peningkatan kualitas packaging dan logo dari merek tersebut, dan memudahkan teknis dalam proses pendaftaran bagi anggota PKK Perak Asri tersebut jika ingin mengembangkan produksi ecoprint menjadi skala lebih besar hingga toko ataupun UMKM, baik didaftarkan secara online maupun mendaftarkan secara offlne ke kementrian Hukum dan HAM. Tidak ada anggota dari PKK Perak Asri yang mengalami ketidakpuasan terhadap kegiatan tersebut. Tingkat kepuasan anggota mitra PKK Perak Asri terhadap kegiatan sosialisasi pendaftaran merek dagang pada Gambar 6.

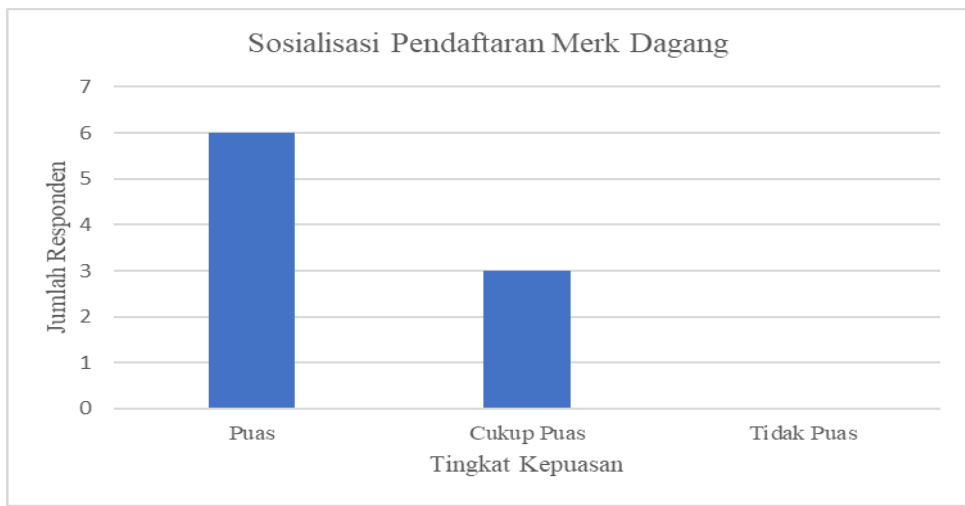

Gambar 6. Tingkat kepuasan anggota mitra PKK Perak Asri terhadap kegiatan sosialisasi pendaftaran merek dagang

Kegiatan ini didukung oleh pemateri dari anggota tim pengabdian yaitu Ir. Diah Rina Kamardiani, M.P. Dokumentasi kegiatan pendaftaran merek dagang yang telah dilakukan sebagai berikut Gambar 7. 


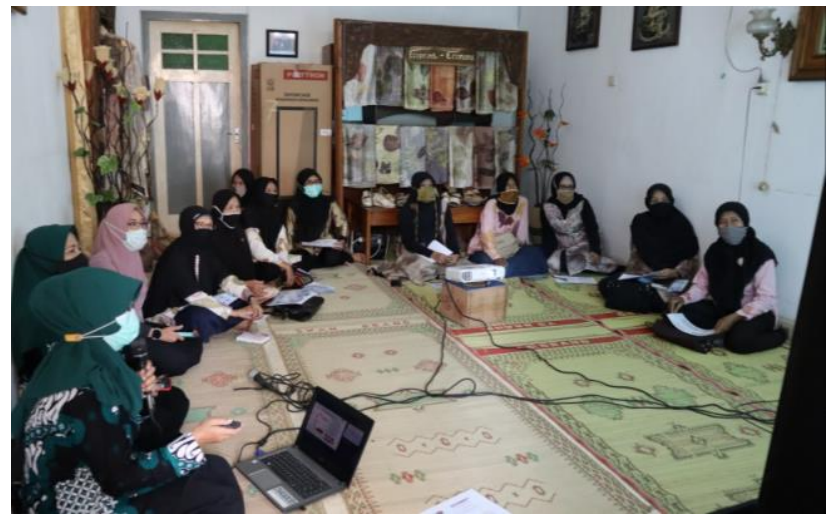

Gambar 7. Dokumentasi kegiatan pendaftaran merek dagang kepada PKK Perak Asri

\section{Penyuluhan dan Pendampingan Materi Produksi Ecoprint dengan Metode Dye Blanket}

Dilakukan kegiatan pelatihan dan monitoring kegiatan dye blanket sebagai kegiatan praktik untuk meningkatkan kedalaman materi dan keterampilan ibu ibu PKK Perak Asri dalam keterbatasan dalam teknik mencetak pola motif dari material alami dan menunjukkan keindahan anatomi tumbuhan maupun penataannya. Kegiatan ini terlaksana pada tanggal 3 Oktober 2020, dokumentasi kegiatan dapat dilihat pada Gambar 8 berikut.

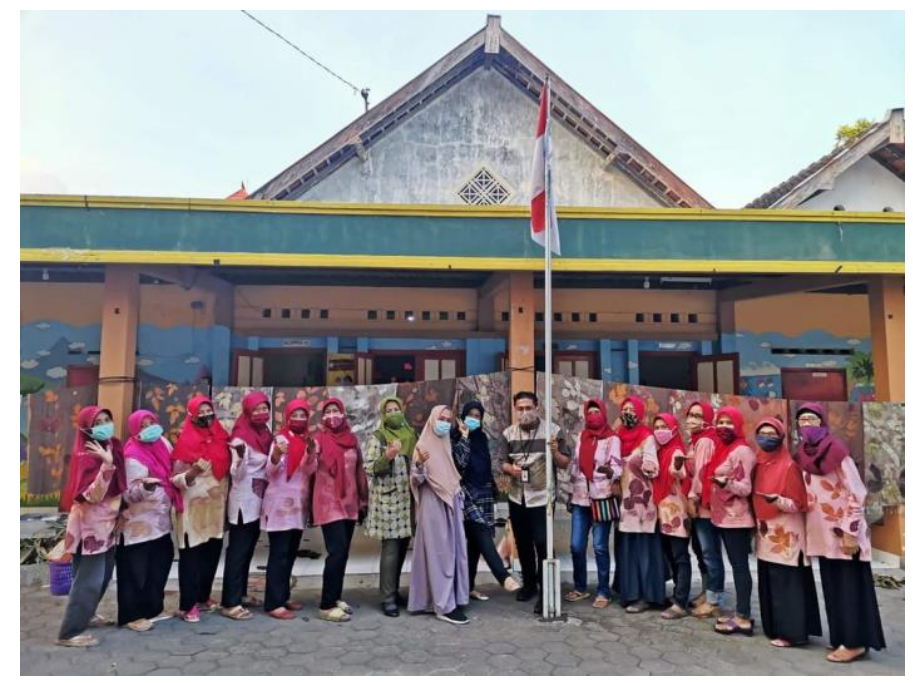

Gambar 8. Pelatihan dye blanket produksi ecoprint kepada PKK Perak Asri

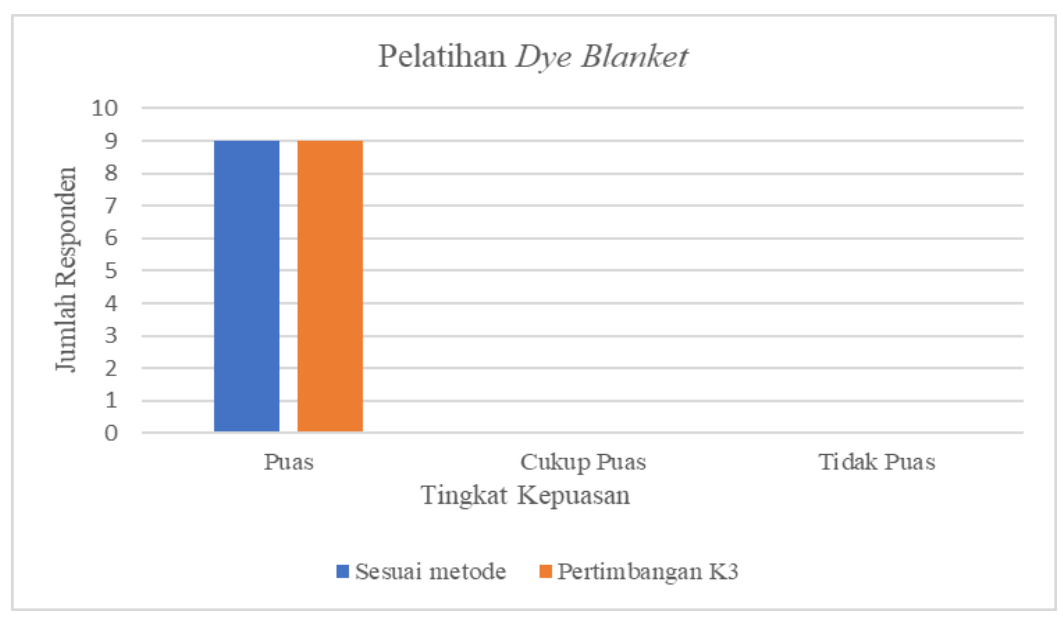

Gambar 9. Tingkat kepuasan terhadap pelatihan metode dye blanket terhadap anggota mitra PKK Perak Asri 
Kepuasan mitra terhadap kesesuaian metode dan pertimbangan K3 dalam kegiatan ini mencapai 100 persen, dapat dilihat pada Gambar 9.

\section{Tingkat Kepuasan Pelaksanaan Seluruh Program dan Stimulasi Minat Bisnis bagi PKK Perak Asri}
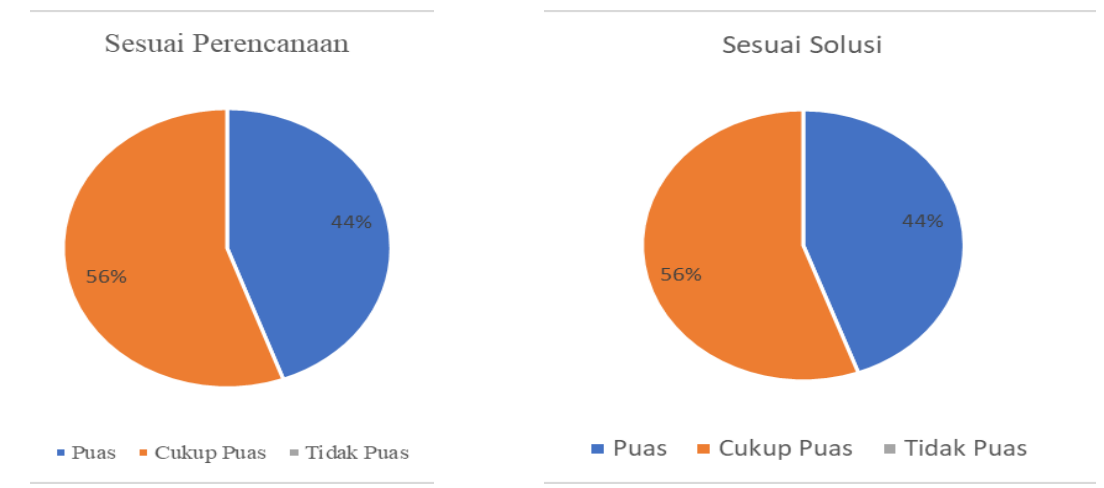

Pemanfaatan secara maksimal

Gambar 10. Tingkat kepuasan terhadap keseluruhan program kegiatan kemitraan masyarakat terkait dengan kesesuaian perencanaan, kesesuaian solusi dan pemanfaatan

Dari keseluruhan program yang terlaksana, kemudian diobservasi apakah dari tiap anggota PKK Perak Asri memiliki tingkat kepuasan program yang tinggi terkait dengan kesesuaian rencana, kesesuaian solusi maupun pemanfaatan maksimal program bagi PKK Perak Asri. Dari Gambar 10 menjelaskan bahwa tidak ada ketidakpuasan dari sejumlah responden dan 56 persen menyatakan puas dan $44 \%$ menyatakan cukup puas atas program dilihat dari kesesuaian perencanaan dan solusi sedangkan persentase 44 persen pada tingkat kepuasan dan 56 persen pada tingkat kepuasan yang cukup, dapat dilihat Gambar 10. Sedangkan, dari kuesioner yang dibagikan, 89 persen responden menyatakan kegiatan ini memiliki tingkat kepuasan tinggi untuk stimulasi minat bisnis, Gambar 11.

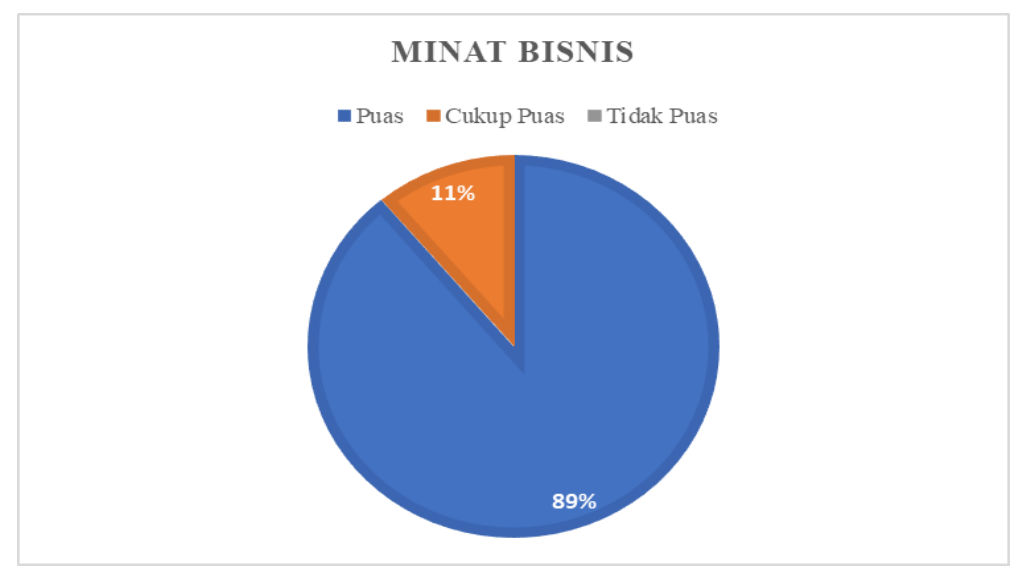

Gambar 11. Tingkat kepuasan terhadap stimulasi minat bisnis terhadap anggota mitra PKK Perak Asri

Sebagai penutup kemudian, PKK Perak Asri mendapatkan fasilitas untuk menanggulangi kendala dalam mengawetkan bahan material tanaman, showcase cooler dan box penyimpan kemudian difasilitasi oleh tim pengabdian masyarakat kepada Ibu ibu PKK Perak Asri. Selain serah terima fasilitas pendukung berupa cooler dan showcase, tim PKK Perak Asri difasilitasi juga alat pengukus untuk media steam sebagai salah satu proses produksi ecoprint. 


\section{Simpulan}

Program kemitraan masyarakat dengan tujuan peningkatan keterampilan PKK Perak Asri Kabupaten Bantul melalui produk ecoprint ramah lingkungan dan berdaya saing secara keseluruhan memberikan tingkat kepuasan kategori puas sebesar 56 persen, kategori cukup puas sebesar 44 persen dilihat dari kesesuaian rencana dan solusi yang digunakan, sedangkan 44 persen sebagai persentase kategori puas dan 56 persen kategori cukup puas terhadap pemanfaatan secara maksimal bagi PKK Perak Asri Kabupaten Bantul, Daerah Istimewa Yogyakarta.

\section{Ucapan Terima Kasih}

Ucapan terimakasih disampaikan kepada LP3M UMY yang telah memberikan dana program kemitraan kepada masyarakat didanai tahun 2020 dengan nomer kontrak 031/PENLP3M/I/2020.

\section{Daftar Pustaka}

Atika Maharani. 2018. Motif dan Pewarnaan Tekstil Di Home Industry Kaine Art Fabric "Ecoprint Natural Dye”. UNY: Skripsi.

Chan, P.M., Yuen, C.W.M. and Yeung, K.W.2002. The Effect Of Natural Dye Effluent On The Environment. Research Journal of Textile and Apparel, Vol. 6 No. 1, pp. 57-62.

K. H. Prabhu and Aniket S Bhute. 2012. Plant based natural dyes and mordants: A ReviewJ. Nat. Prod. Plant Resour., 2012, 2 (6):649-664.

Mutiara Triwiswara. 2015. Natural dye mordants and their health hazards. Dapat diakses pada https://www.researchgate.net/publication/282381262_Natural_dye_mordants_and_their_h ealth_hazards/citations

Tanaka Y, Sasaki N, Ohmiya A. 2008. Biosynthesis of plant pigments: Anthocyanins, betalains, and carotenoids. Plant Journal vol 54(4): 733-749.

Tri Asep S. 2018. Peningkatan Mutu Biodiesel Dari Minyak Jarak Kepyar (Ricinus Communis) Melalui Pencampuran Biodiesel Dari Minyak Nyampung (Calophyllum inophyllum). UMY: Skripsi. 